\title{
Faktor Rasionalitas Swamedikasi Suplemen Yang Mengandung Vitamin C Di Kota Denpasar
}

\author{
Ni Putu Aryati Suryaningsih ${ }^{a, 1^{*}}$, Gde Palguna Reganataa, ${ }^{*}$, Ayunda Deva Rinata ${ }^{a, 3^{*}}$ \\ aUniversitas Bali Internasional, J1 Seroja, Gang Jeruk, Tonja, Denpasar, Bali, 80234 \\ 1aryatisuryaningsih@iikmpbali.ac.id*; ${ }^{2}$ palgunareganata@iikmpbali.ac.id; ${ }^{3}$ email penulis ketiga \\ *korespondensi penulis
}

\begin{tabular}{ll}
\hline INFO ARTIKEL & ABSTRAK \\
\hline Diterima : & Provinsi Bali pada bulan September 2020, memecahkan rekor tertinggi \\
26-I2-202I & penambahan kasus harian Coronavirus Disease (COVID-I9). Peningkatan \\
Direvisi : & pandemik menyebabkan penggunaan suplemen yang mengandung VItamin C \\
05-0I-2022 & meningkat secara signifikan. Penggunaan VItamin C masih sangat tinggi dan \\
Disetujui : & penelitian ini masih sangat terbatas. Penggunaan VItamin C yang meningkat dan \\
05-0I-2022 & tidak sesuai kebutuhan tubuh menyebabkan penggunaan vitamin tersebut tidak \\
& rasional. Penelitian ini bertujuan untuk mengetahui faktor apa saja yang \\
\hline Kata kunci: & mempengaruhi responden dalam swamedikasi suplemen yang mengandung \\
Rasionalitas; & VItamin C. Penelitian ini merupakan deskriptif kuantitatif dengan Rancangan \\
Swamedikasi; & penelitian cross-sectional pada masyarakat kota Denpasar periode Januari- Juni \\
Suplemen; & 202I. Hasil penelitian di dapat responden terbanyak dalam swamedikasi di Usia \\
Vitamin C. & Remaja Akhir sebanyak 49,5\% terlihat paling banyak di Denpasar Barat \\
& terbanyak sebesar 3I,4 \%, dengan Jenis kelamin perempuan sebanyak $68,6 \%$. \\
& Tingkat pendidikan tinggi paling banyak sebesar $51,4 \%$ dengan Jenis suplemen \\
& Enervon C sebanyak 4I\% dan sumber Informasi terbanyak dari Tenaga \\
Kesehatan sebanyak 4I,9\%. Faktor yang mempengaruhi rasionalitas \\
swamedikasi adalah tingkat pendidikan dan sumber informasi dengan $p=0,00 I$ \\
dan $p=0,009$
\end{tabular}

Key word:

Rationality;

Swamedication;

Suplement;

Vitamin C;

\section{ABSTRACT}

Province Bali in September 2020, the highest daily addition of cases of Coronavirus Disease (COVID-19). The increase in pandemic caused the use of supplements containing VItamin C significantly. The use of VItamin C is still very high and this research is very limited. The Increase use of VItamin $C$ and does not match the body's needs causes the use of this vitamin to be irational. This research aims to factors influence of respondents in swamedication supplements containing VItamin C. This study is a quantitative descriptive with a cross-sectional approaches in Denpasar for the January-June $202 \mathrm{I}$ period. In this study, the late teen as much as $49,5 \%$ was seen the most, the West Denpasar area was the most at $31,4 \%$, with female as $68.6 \%$. The highest level of higher education as $5 \mathrm{I}, 4 \%$ with Enervon $\mathrm{C}$ supplements as much as $4 \mathrm{I} \%$, and the largest sources of information is from Health Workers as much as 4I,9\%. Factors that influences the rationality in swamedication are the evel of education and sources of information with $p=0,00 I$ and $p=0,009$.

This is an open access article under the CC-BY-SA license.

\section{Pendahuluan}

Wabah penyakit yang bernama Coronavirus Disease (COVID-19) mempunyai dampak cukup besar disemua sektor kehidupan manusia. Provinsi Bali tercatat pada tanggal 4 September 2020 memecahkan rekor tertinggi penambahan kasus harian dengan penambahan 196 kasus positif dan 9 dari permasalahan serta pasien yang meninggal dunia (Satgas COVID-19 Provinsi Bali, 2019). Organisasi Kesehatan Dunia (WHO) menyarankan selama pandemikCOVID-I9 untuk mengonsumsi makanan sehat serta meningkatkan kekebalan tubuh dengan 
perbanyak vitamin. Berdasarkan Keputusan Menteri Kesehatan Republik Indonesia tentang Pedoman Pencegahan dan Pengendalian Corona Virus Disease 2019 dan buku tatalaksana terapi yang dikeluarkan oleh Perhimpunan Dokter Paru di Indonesia menetapkan farmakologi pasien COVID- 19 dengan suplemen yang mengandung VItamin $\mathrm{C}$ dan guna membantu pertahanan daya tahan tubuh dengan pemberian suplemen VItamin C (Kepmenkes RI, 2020; PDPI 2020). Studi pendahuluan telah dilakukan di 4 Apotek kawasan Kota Denpasar, didapatkan hasil bahwasebelum pandemik COVIDI9 penjualan suplemen yang mengandung VItamin C hanya $10 \%$ dari total penjualan perharinya, sedangkan pada saat pandemik COVID-I9 pada bulan maret - april 2020, terjadi peningkatan yang sangat signifikan yaitu $75 \%$ dari total penjualan per harinya. Rata-rata masyarakat mencari suplemen VItamin C diatas $500 \mathrm{mg}$. Ada kepercayaan luas bahwa VItamin C memperkuat sistem kekebalan tubuh dan karenanya bisabekerja untuk mengobati atau mencegah pernafasan infeksi (Siswanto and Ernawati, 20I4). Walaupun belum ada bukti ilmiah yang mampu menunjukan bahwa suplemen yang mengandung VItamin $\mathrm{C}$ mampu mengatasi COVID-19, tetapi sudah banyak masyarakat yang melakukan swamedikasi dengan mengonsumsi suplemen yang mengandung VItamin C khususnya di Kota Denpasar.

Swamedikasi adalah pemilihan dan penggunaan obat modern, herbal, maupun obat tradisional oleh seorang individu untuk mengatasi penyakit atau gejala penyakit yang disadarinya. Pelaksanaan swamedikasi harus memenuhi kriteria penggunaan obat rasional. Menurut penelitian yang di lakukan oleh Harahap (2017) dari 342 responden terdapat 139 responden (40,6 \%) yang menggunakan obat secara swamedikasi yang tidak rasional dan 203 responden (59,4\%) yang menggunakan obat secara swamedikasi yang rasional (Harahap, Khairunnisa and Tanuwijaya, 2017). Penggunaan Obat Secara Rasional (POR) merupakan suatu kampanye yang disebarkan ke seluruh dunia, juga di Indonesia. World Health Organization (WHO) dalam situsnya menjelaskan bahwa definisi Penggunaan Obat Secara Rasional adalah apabila pasien menerima pengobatan sesuai dengan kebutuhan klinisnya, sesuai dengan dosis kebutuhan, sesuai periode waktu yang butuhkan dan dengan biaya yang terjangkau oleh kebanyakan masyarakat dan dirinya. Melalui empat kunci yaitu kebutuhan klinis, dosis, waktu dan biaya yang sesuai. Penggunaan suplemen yang mengandung VItamin C jika tidak sesuai dengan dosis yang direkomendasikan akan mengakibatkan penggunaannya tidak rasional, serta dapat mengakibatkan kerusakan pada organ tubuh seperti ginjal jika dikonsumsi secara berlebihan (Health, 2004).

Mengkonsumsi suplemen yang mengandung VItamin C akan lebih efektif bila sesuai dengan dosis yang disarankan oleh dokter dan sesuai dengan indikasi penyakit (Unja, 2020). Rasionalitas obat dapat diukur dengan parameter (Tepat Indikasi, Tepat Penyimpanan Obat, Tepat Dosis, Tepat Cara Pemberian, Tepat Lama Pemberian dan Waspada Efek Samping) (Kemenkes, 20II). Guna mengumpulkan data penggunaan suatu obat dikatakan rasional dapat dilakukan dengan metode kuesioner/angket. Analisis yang digunakan uji validasi dan reliability. Berdasarkan data dari studi pendahuluan, penggunaan VItamin $\mathrm{C}$ masih sangat tinggi dan penelitian ini masih sangat terbatas. Serta instrument tentang rasionalitas suplemen yang mengandung Vitamin $\mathrm{C}$ yang ada di Indonesia belum teruji secara tepat dalam kaidah-kaidah pengembangan instrument. Oleh karena itu, maka peneliti tertarik untuk melakukan penelitian mengenai pengembangan kuesioner rasionalitas swamedikasi suplemen yang mengandung VItamin C di Kota Denpasar dengan harapan dapat melakukan uji validitas dan reliabilitas kuesioner terkait rasionalitas swamedikasi supplement yang mengandung VItamin C di Kota denpasar yang bertujuan untuk mengukur sah/valid atau tidaknya butir kuisioner. Selanjutnya, peneliti ingin mengetahui faktor apa sajakah yang mempengaruhi Rasionalitas dalam Swamedikasi Penggunaan Suplemen Yang Mengandung Vitamin C

\section{Metode}

Penelitian ini merupakan penelitian dengan pendekatan kuantitatif. Pendekatan kuantitatif dengan analisis statistik dalam pengolahan data yang menghasilkan data berupa angka. Penelitian ini dilakukan di 4 Instansi kesehatan untuk proses validasi isi dan wilayah Denpasar untuk proses validasi kuisioner dilakukan face validity dan konstruk validity. Izin kelayakan etik diperoleh dari Komite Etik Fakultas Kedokteran Universitas Udayana/Rumah Sakit Umum Sanglah Pusat Sanglah Denpasar. Penelitian ini merupakan bagian dari survey rasionalitas swamedikasi suplemen yang mengandung VItamin C dalam upaya preventif COVID-I9.

Uji validitas konstruk bertujuan untuk menilai butir pernyataan kuesioner apakah sudah mampu mengukur apa yang benar diukur sesuai konsep yang telah ditetepkan. Uji coba ini dilakukan pada 38 responden yang mengonsumsi suplemen yang mengandung VItamin C di Kota Denpasar. Teknik pengujian yang digunakan untuk uji validitas 
konstruk adalah menggunakan korelasi Pearson Corelation. Analisis ini dengan cara mengkorelasikan masing-masing skor item dengan skor total. Skor total adalah penjumlahan dari keseluruhan item. Item-item pertanyaan yang berkolerasi signifikan dengan skor total menunjukan item-item tersebut mampu memberikan dukungan dalam mengungkap apa yang ingin diungkapkan. Jika $\mathrm{r}$ hitung $\geq \mathrm{r}$ table (uji 2 sisi dengan sig. 0.05) maka instrument atau item-item pertanyaan berkolerasi signifikan terhadap skor total (dinyatakan valid) (Kline, 2000; Portney \& Watkins, 2009; Terwee et al. 2007). Uji Reliabilitas bertujuan untuk mengetahui apakah alat pengumpulan atau kuesioner tersebut menunjukan tingkat ketepatan, kestabilan, atau konsisten walaupun dilakukan dalam waktu berbeda. Uji ini mengukur apakah alat ukur cukup dapat dipercaya untuk digunakan sebagai alat ukur. Uji reliabilitas menggunakan Alpha Cronbach (C $\alpha)$ dengan menggunakan SPSS. tingkat reliabilitas memadai jika koefisien Alpha Cronbach lebih besar atau sama dengan 0,60 (Sundayana, 2016).

Kuisioner yang ada digunakan untuk menganaliis faktor yang mempengaruhi rasionalitas Swamedikasi Suplemen yang Mengandung VItamin C di Kota Denpasar.

\section{Hasil dan Pembahasan}

Responden dalam penelitian swamedikasi dalam menggunanakan suplemen yang mengandung VItamin C ini secara usia terlihat paling banyak pada rentang usia remaja Akhir yaitu usia 17-25 tahun sebanyak $49,5 \%$. Hal ini sejalan dengan penelitian yang dilakukan oleh putu udayana antari tahun 202I dalam penelitian Korelasi Pemahaman Covid-19 dan Penggunaan Suplemen yang terlihat sebanyak 92 Responden dengan usia 17-25 tahun (Udayana,202I dan Aryati 202I). Hal ini menjadi sangat wajar bila mengingat usia ini adalah termasuk kedalam usia produktif dan pada umumnya memiliki daya ingat dan daya tangkap yang baik serta memiliki kedawasaan dalam berfikir. Pada kelompok usia ini merupakan kelompok usia produktif yang memiliki mobilitas tinggi sehingga membutuhkan suplemen vitamin untuk menunjang aktivitasnya (Ade Wulandari, 20I4).

Berdasarkan lokasi penelitian, disini terlihat di daerah Denpasar barat yang terlihat paling banyak sebesar 3I,4\%, Hal ini sejalan dengan data pusatdata Denpasar kota yang menunjukkan dimana penduduk kota Denpasar yang paling banyak yaitu di wilayan Denpasar barat. Jenis kelamin dalam penelitian ini didominasi oleh jenis kelamin perempuan sebanyak $68,6 \%$. Hal ini secara umum, memang responden perempuan lebih banyak mengisi kuesioner dibanding laki-laki. Faktor jenis kelamin dapat mempengaruhi keinginan dan kemampuan masyarakat untuk berpartisipasi. Biasanya pemikiran laki-laki dan perempuan mengenai suatu permasalahan berbeda sudut pandangnya. Selain itu jenis kelamin juga dapat mempengaruhi dalam penggobatan sendiri, seperti yang terlihat dalam penelitian yang dilakukan oleh Kristina,dkk menunjukkan jenis kelamin perempuan lebih cenderung melakukan pengobatan sendiri yang rasional dibandingkan dengan jenis kelamin laki-laki dan perempuan lebih sering melakukan pengobatan dibandingkan laki-laki (Kristina 2007, dan Aryati 202I).

Berdasarkan tingkat Pendidikan, pada penelitian ini Pendidikan tinggi lebih banyak sebebsar 5I,4 \%. \%. Kondisi ini sejalan dengan penelitian Kristina $\mathrm{dkk}$, yang mengatakan bahwa faktor pendidikan berpengaruh besar terhadap swamedikasi dimana tingkat pendidikan tinggi paling banyak melakukan swamedikasi secara rasional. Hal ini juga sejalan dimana responden dengan tingkat Pendidikan lebih banyak dalam Penelitian yang dilakukan oleh Lydia karena tingkat Pendidikan akan menentukan mudah tidaknya seseorang dalam memahami pengetahuan yang diperoleh. Oleh karena itu, responden dengan tingkat pendidikan tinggi akan cenderung memiliki pemahaman ataupun pengetahuan yang cukup mengenai pengobatan nyeri sehingga mendorong mereka untuk melakukan pengobatan tanpa berkonsultasi ke dokter atau swamedikasi. (Kristina 2007, Lydia 202I)

Sumber informasi pada penelitian ini terlihat responden memperoleh informasi paling banyak dari Tenaga kesehatan, hal ini dikarenakan banyaknya pasien yang langsung datang ke apotek dan menyakan kepada Apoteker ataupun tenaga kesehatan yang bertugas terkait dengan suplemen apa yang sebaiknya mereka gunakan. Selain itu berdasarkan wawancara dengan responden, ada beberapa responden yang mengatakan mereka memperoleh informasi dari kerabat mereka yang bekerja sebagai Tenaga kesehatan sebelum mereka datang ke Apotek untuk membeli suplemen/vitamin. Hal ini sejalan dengan penelitian yang dilakukan terkait dengan swamedikasi oleh Lydia, dimana pasien lebih banyak memperoleh informasi dari apoteker (Lydia, 202I). Selain itu hubungan antara komunikasi dan outcome terapi menunjukkan bahwa Clinical communication memiliki hubungan yang signifikan terhadap kesuksesan terapi (positive health outcome).

Profil Rasionalitas dalam Swamedikasi Suplemen yang mengandung VItamin C dilihat dari beberapa kriteria. Kriteria rasionalitas yang diamati pada penelitian ini meliputi Tepat Indikasi, Tepat 
Dosis, Tepat Cara pemberian, Tepat penyimpanan obat, dan Waspada Efek Samping. Gambaran Rasionalitas dalam Swamedikasi Suplemen yang mengandung VItamin $\mathrm{C}$ pada penelitian ini diperoleh hasil sebanyak 48,6\% responden diketahui lebih rasional dalam menggunakan suplemen yang mengandung VItamin C. Responden dalam penelitian ini kurang tepat dalam mengisi kusioner pada kriteria Tepat Cara Pemberian. Hal ini sejalan dengan penelitian yang dilakukan

Karakteristik dalam penelitian ini dianalisis dengan menggunakan $\mathrm{Uji}_{\mathrm{j}}$ Chi-Square untuk mengetahui faktor yang mempengaruhi dalam rasionalitas dalam swamedikasi suplemen yang mengandung VItamin C.

Pada penelitian ini faktor faktor yang dianalisis Usia, Jenis Kelamin, Area tempat tinggal, Pendidikan, Jenis suplemen, dan Sumber informasi. Analisis yang digunakan Chi-Square, berdasarkan hasil analisis menggunakan Chi-Square, Usia, Jenis kelamin, Area tempat tinggal, dan Jenis suplemen menunjukkan tidak ada pengaruh dengan rasionalitas. Penelitian ini sejalan dengan penelitian yag dilakukan oleh Nur Aini Harahap pada tahun 2017 dalam penelitiannya rasionalitas dalam swamedikasi menunjukkan bahwa tidak adanya pengaruh rasionalitas penggunaan obat swamedikasi dengan faktor usia dan jenis kelamin.

Faktor-faktor yang berhubungan dengan penggunaan obat rasional (rational use of drug) dalam swamedikasi pada tahun 2017 di Jakarta Selatan, dimana diketahui tidak dipengaruhi factor sosiodemography. Hasil dari penelitian ini menunjukkan bahwa responden yang menggunakan obat secara tidak rasional sebanyak 54 orang (51,4\%)

Pendidikan dan sumber informasi dalam penelitian ini diketahui memiliki pengaruh terhadap rasionalitas dengan nilai $\mathrm{p}=0,00 \mathrm{I}$ dan $\mathrm{p}=0,009$. Hal ini sejalan dengan penelitian perilaku pengobatan sendiri yang rasional pada masyarakat. Pada penelitian tersebut diketahu responden dengan pendidikan tinggi tidak mudah terpengaruh dengan iklan obat di media dan lebih banyak membaca label pada kemasan obat sebelum mengkonsumsi obat. Penelitian ini juga sejalan dengan penelitian yang dilakukan Lydia 202I.

Sumber informasi memiliki pengaruh terhadap rasionalitas penggunaan supelemen yang mengandung Vitamin C, dimana diketahui responden yang mendapatkan informasi oleh tenaga kesehatan lebih rasional dibandingkan dengan sumber informasi lainnya. Hal ini sejalan dengan penelitian tentang peran tenaga kesehatan dalam promosi kesehatan dimana diketahui bahwa ada hubungan peran tenaga promosi kesehatan pada germas dengan pencegahan penyakit tidak menular.Informasi yang didapat selain dari tenaga kesehatan juga diperoleh dari media sosial dan media elektronik. Hal ini sejalan dengan penelitian yang dilakukan oleh Aryati dimana masyarakat sebanyak $73 \%$ memperoleh informasi pengobatan melalui media sosial. (Aryati, 202I) Penelitian Lydia dkk juga menunjukkan dimana dalam swamedikasi sangat dipengaruhi oleh tersedianya berbagai media informasi di masyarakat, sehingga hal tersebut dapat mempengaruhi penggunaan obat di masyarakat. Dengan telah tersedianya berbagai informasi (internet, keluarga, maupun lingkungannya) terkait penggunaan obat di masyarakat, sehingga masyarakat tidak perlu memiliki latar belakang pendidikan yang tinggi untuk melakukan swamedikasi dengan tepat, (Ni Putu Lydia)

\section{Simpulan dan Saran}

Berdasarkan hasil penelitian yang telah dilakukan, maka dapat disimpulkan : I). Responden dalam penelitian swamedikasi dalam menggunanakan suplemen yang mengandung VItamin C ini secara Usia terlihat paling banyak pada rentang Usia Remaja Akhir yaitu Usia 17-25 tahun sebanyak $49,5 \%$. Wilayah denpasar yang paling banyak di Denpasar barat sebesar 31,4 \%, dengan Jenis kelamin yang didominasi oleh jenis kelamin perempuan sebanyak 68,6 \%. Berdasarkan tingkat Pendidikan, pada penelitian ini Pendidikan tinggi lebih banyak sebebsar 5I,4\%. Jenis suplemen yang digunakan dalam penelitian terlihat paling banyak yaitu jenis suplemen Enervon C sebanyak 41\% dan Sumber Informasi terbanyak didapat dari Tenaga kesehatan sebanyak $41,9 \% ; 2)$. Faktor faktor dari karakteristik yang diketahui memiliki pengaruh terhadap rasionalitas adalah tingkat pendidikan dan sumber informasi. Simpulan ditulis secara jelas, singkat, dan dalam satu paragraf, yang merupakan ringkasan dari hasil dan pembahasan serta menjawab dari tujuan dari penelitian. Menekankan pada kebaharuan dari penemuan atau pengembangan.

Saran dari penelitian ini, perlu dilakukan penelitian lanjutan untuk melihat bagiamana pengartuh dari factor factor tersebut dalam mempengaruhi rasionalitas dalam swamedikasi.

\section{Ucapan Terima Kasih}

Terimakasih kepada Universitas Bali Internasional telah membiayai seluruh penelitian ini, dan juga kepada tenaga Kesehatan yang masuk dalam ecpert dalam penelitian ini. 


\section{Daftar Pustaka}

BPOM RI. (2020a). Buku saku Suplement Kesehatan Untuk Memelihara Daya Tahan Tubuh Dalam Menghadapi COVID-I9. Badan Pengawasan Obat dan Makanan Republik Indonesia.

BPOM RI. (2020b). Informatorium Obat COVIDI9 Di Indonesia. Badan Pengawasan Obat dan Makanan Republik Indonesia.

Cahya, P. L. \& P. (20I5). Literasi Informasi tentang Kemasan Produk Obat Bebas. 2, 357375.

https://doi.org/I0.36525/sanitas.2019 .10

Carr, A. C. and Maggini, S. (2017). VItamin C and immune function. Nutrients, 9(II), I25.

https://doi.org/I0.3390/nu9I I I2I I

CDC. (2020). Vaccines Testing and the Approval Procrss. Prevention, Centers for Disease Control And. https://www.cdc.gov/vaccines/basics/t est-approve.html

Chen N, Zhou M, Dong X, et al. (2020). Epidemiological and clinical characteristics of 99 cases of 2019 novel coronavirus pneumonia in Wuhan, China. A Descriptive Study, 507-5I3. https://doi.org/IO.IOI6/ SOI406736(20)302I I-7

Cheng RZ, Kogan M, D. D. (2020). Ascorbate as Prophylaxis and Therapy for COVIDI9-Update From Shanghai and U.S. Medical Institutions. Glob Adv Heal Med,

9. https://doi.org/2I64956I2093476

Chotimah, C. (2003). Perilaku konsumsi suplemen pada wanita dewasa di Kota Bogor. Institut Pertanian Bogor.

Depkes RI. (2006). Kriteria Penggunaan Obat Rasional. Departemen Kesehatan RI.

Depkes Republik Indonesia. (n.d.). Pedoman Pencegahan dan Pengendalian Corona Disease (COVID-I9). Germas, 0-II5.

E. S. Wintergerst, S. M. and D. H. H. (2006). Immune-Enhancing Role of VItamin C and Zinc and Effect on Clinical Conditions. Annals of Nutrition and Metabolism, 50(2), 85-94. http://dx.doi.org/IO.I I59/000090495

Erlina B, Fathiyah I, A. D. S. (2020). Pneumonia COVIDI9. Diagnosis dan Tatalaksana di Indonesia. Perhimpunan Dokter Paru Indonesia.
Haenen, G R R M., \& A. B. (2002). The use of vitamin supplements in self-medication. PMC Article, 57(2), II9-I22.

Harahap, N. A., Khairunnisa, K., \& Tanuwijaya, J. (2017). Patient knowledge and 39 rationality of self-medication in three pharmacies of Panyabungan City, Indonesia. Jurnal Sains Farmasi \& Klinis, $3(2)$,

I86. https://doi.org/I0.29208/jsfk.2017.3. 2.124

Health, V. (2004). Seluk Beluk Food Suplemen. PT Gramedia Pustaka Utama.

Jacob, R, A,. \& Soutoudeh, F. G. (2002). VItamin C Function and status in Chronic Disease. 5(2), 66-72.

Kristina, S. A., Prabandari, Y. S., \& Sudjaswadi, R. (2007). Perilaku Pengobatan Sendiri Yang Rasional Pada Masyarakat. Berita Kedokteran Masyarakat, 23(4), 176.

Massey LK, et al. (2005). Ascorbate Increases Human Oxaluria and Kidney Stone Risk. F Nutr, 135:1673.

NADA, Q. (2018). Faktor-Faktor Yang Berhubungan Dengan Penggunaan Obat Rasional (Rational Use Of Drug) Dalam Swamedikasi Pada Ibu Dalam Rangka Program Gema Cermat Di Wilayah Rt 02/007 Kelurahan Srengseng Sawah Jakarta Selatan. Qotrun Nada. Universitas Pembangunan Nasional "Veteran" Jakarta.

Ni Putu Aryati Suryaningsih, Gde Palguna Reganata , Ida Ayu Manik Partha Sutema, D. W. B. P. (202I). Rasionalitas Dalam Swamedikasi VItamin C Pada Masa Pandemi Covid - I9 Di Kota Denpasar. Bali Medika Jurnal, 8, I80-I90. https://doi.org/https://doi.org/I0.363 76/bmj.v8i2

Ni Putu Lydya, Ni Putu Aryati Suryaningsih, N. made U. K. D. (202I). Rasionalitas Penggunaan Analgesik Dalam Swamedikasi Nyeri Di Kota Denpasar. Riset Kesehatan Nasional, 5(I). http://dx.doi.org/I0.37294/jrkn.v5iI

Ni Putu Udayana Antari, Ni Putu Leona Yorita Dewi, I Wayan Mahardika Saputra, Nyoman Ayu Prascitasari, Ni Putu Ayu Dhea Arkhania, Ni Nyoman Zelina Aswindari, Ni Putu Hera JuliariI , Ni Kadek Novi Andarista , Anak Agung Ngurah Dwi Kosalawa, Ni Ketut Ap, I. G. B. S. (n.d.). Korelasi antara Pemahaman Covid-I9 dan Penggunaan Suplemen. 
Fakultas Farmasi Universitas

Mahasaraswati Denpasar, 7(I), I-6. https://doi.org/http://doi.org/I0.367

33/medicamento.v7iI.I029 e-ISSN:

2356-48I4

NIH. (2020). VItamin C Fact Sheet For Health Professionals Introduction. NIH (National Institue of Health) Office of Dietary Supplements.

Nur Aini Harahap, Khairunnisa, J. T. (2017). Tingkat Pengetahuan Pasien dan Rasionalitas Swamedikasi di Tiga Apotek Kota Penyambungan,. In Jurnal Sains dan Klinis. Ikatan Apoteker Indonesia.

Rina, Winda Martha, Abidillah Mursyid, dan W. K. (2009). Perbedaan Tingkat Pengetahuan Terhadap Konsumsi Suplement Pada Anggota Klub Olahraga YUSO (Yuwana Sarana Olahraga Sleman”. Jurnal Nutrisis.

Susi Ari Kristina, Yayi Suryo Prabandari, R. S. (2007). Perilaku Pengobatan Sendiri Yang Rasional Pada Masyarakat. Berita Kedokteran Masyarakat, 23(4).

Wardiyah, N. P. \&. (2019). The Development of Motion Graphic as Education Material For Promoting Adequate Home Drug Storage. 10, 92-I01.

WHO. (2000). Guidelines for the Regulatory Assessment of Medicial Products for Use in Self-Medication. In World Health Organization. World Health Organization. https://doi.org/I0.I038/clpt.2008.254

Wulandari, A. (2014). Karakteristik Pertumbuhan Perkembangan Remaja Dan Implikasinya Terhadap Masalah Kesehatan Dan Keperawatannya. Keperawatan Anak, 2, 39-43. 